Al Maal : Journal of Islamic Economics and Banking

http://jurnal.umt.ac.id/index.php/jieb

E-ISSN : $\quad 2580-3816$

Vol : 3 No. 1 Bulan Juli Tahun 2021

Hlm : $25-34$

DOI : $\quad$ : 10.31000/almaal.v3i1.4637

\title{
Penerapan Akad Ar-Rahn Pada Produk Mulia di PT. Pegadaian Unit Syariah Sigli
}

\author{
Melati Sari Maisara ${ }^{1^{*}}$ \\ ${ }^{1}$ Hukum Ekonomi Syariah, STIS PTI AL-HILAL Sigli, Aceh, Indonesia \\ *melatisari5998@gmail.com
}

\section{ABSTRACT}

This study aims to look at the implementation of the ar-rahn contract on Mulia products at the Sigli Sharia Pawnshop unit so far in the practice of the Sigli Sharia Pawnshop and see the level of conformity with the concept of Islamic law. The research method used is descriptive method, literature review and conducting field research. The techniques used in data collection are observation, documentation and interview techniques. The results showed that the provisions and mechanisms of the Mulia product at the Sigli Syariah Unit Pegadaian used the ar-rahn contract as the main contract of the Mulia product by paying a 15\% down payment, the object of this contract was precious metal gold, funds and costs that must be borne by customers such as, the cost of maintaining and maintaining goods, administrative costs and late fees of a minimum of $2 \%$ and a maximum of $4 \%$ which will burden the customer and can potentially refer to gharar. Cost management at the Sigli Syariah Pawnshop unit stipulates the existence of administrative costs based on the amount of real costs incurred, such as; equipment costs and labor costs as well as rahin guaranteed by the insurance company. According to Islamic law, the application of the ar-rahn contract on Mulia products is considered valid because of the clarity between the two parties and mutual pleasure. However, in practice, the customer is still at a disadvantage because of the storage costs of collateralized goods, as well as administrative costs which in turn can potentially lead to gharar.

Keywords: Application; Ar-Rahn; Islamic law; Mulia products.

\section{ABSTRAK}

Penelitian ini bertujuan untuk melihat penerapan akad ar-rahn pada produk Mulia di Pegadaian Unit Syariah Sigli selama ini di praktikkan Pegadaian Unit Syariah Siglidan melihat tingkat kesesuaiannya dengan konsep hukum Islam. Hasil penelitian menunjukkan bahwa ketentuan dan mekanisme produk Mulia di Pegadaian Unit Syariah Sigli menggunakan akad ar-rahn sebagai akad pokok produk Mulia dengan membayar uang muka 15\%, objek dari akad ini adalah emas logam Mulia dana dan biaya-biaya yang harus ditanggung oleh nasabah seperti, biaya pemeliharaan dan perawatan barang, biaya administrasi serta denda keterlambatan minimal $2 \%$ dan maksimal 4\% yang mana akan memberatkan pihak nasabah dan dapat berpotensi merujuk kepada gharar. Pengelolaan biaya pada Pegadaian Unit Syariah Sigli menetapkan adanya biaya administrasi yang berdasarkan besarnya biaya Rill yang dikeluarkan, seperti; biaya perlengkapan dan biaya tenaga kerja serta rahin dijaminankan pada perusahaan asuransi. Menurut hukum Islam penerapan akad ar-rahn pada produk Mulia ini dipandang sah karena adanya kejalasan antara kedua belah pihak serta saling ridha. Akan tetapi dalam praktinya nasabah tetap dirugikan karena adanya biaya penyimpanan atas barang jaminan, serta biaya administrasi yang gilirannya bisa berpotensi menimbulkan gharra.

Kata kunci: Penerapan; Ar-Rahn; Hukum Islam dan Produk Mulia. 


\section{Pendahuluan}

Pegadaian syariah merupakan lembaga keuangan yang memberikan kemudahan bagi masyarakat untuk memenuhi kebutuhan dan membantu masyarakat yang mengalami kesulitan dalam hal keuangan. Salah satu pembiayaan yang ditawarkan oleh pegadaian syariah dan sedang digemari oleh masyarakat adalah Pembiayaan Mulia (Logam Emas Batangan) merupakan pembiayaan dengan menggunakan akad ar-rahn sebaga akad pokok yang terdapat di pegadaian syariah yang memfasilitasi kepemilikan emas melalui penjualan Logam Mulia, baik oleh pegadaian syariah kepada masyarakat secara tunai dan atau dengan pola angsurproses yang cepat dalam jangka waktu tertentu yang fleksibel. Pembiayaan Mulia ini menggunakan akad ar-rahn sebagai akad pokok. (Nurlaili Maghfirah, 2018).

Perlu diketahui bahwa Produk Mulia di sini menggunakan akad ar-rahn (Syamsul Anwar, 2007) dengan prosedural menahan barang jaminan yang bersifat materi milik si peminjam (rahin) sebagai jaminan atas pinjaman yang diterimanya. Barang jaminan tersebut bernilai ekonomi, sehingga pihak yang menahan (murtahin) memperoleh jaminan untuk mengambi kembali seluruh atau sebagian utangnya dari barang gadai dimaksud, jika pihak yang menggadaikan tidak dapat membayar utang pada waktu yang ditentukan.

Sifat ar-ahn secara umum dikategorikan sebagai akad yang bersifat derma, sebab apa yang diberikan penggadai (rahin) kepada penerima gadai (murtahin) tidak ditukar dengan sesuatu. Pinjaman yang diberikan murtahin kepada rahin adalah utang, bukan penukar atas barang yang digadaikan. (Rachmat Syaf'i, 2001)

Ar-rahn adalah menahan salah satu harta milik si peminjam sebagai jaminan atas pinjaman yang diterima. Barang yang ditahan tesebut harus memiliki nilai ekonomi. Dengan demikian, pihak yang menahan memperoleh jaminan untuk dapat menambil kembali seluruh atau sebagai piutangnya seperti yang kita ketahui bahwa biasanya arrahn digunakan sebagai jaminan untuk mendapatkan suatu pembiayaan yang sangat mendesak dan sering juga dijadikan jaminan untuk pembelian yang ditangguhkan dengan pembayaran yang tidak tunai atau secara kredit. Dengan kata lain, ar- rahn adalah suatu kegiatan hutang piutang antara kedua belah pihak, dengan menjadikan suatu barang yang berharga atau bernilai sebagai jaminannya.

Berdasarkan pra penelitian diketahui bahwa ar-rahn digunakan sebagai jaminan untuk mendapatkan suatu pembiayaan yang sangat mendesak dan sering juga dijadikan jaminan untuk pembelian yang ditangguhkan dengan pembayaran yang tidak tunai atau secara kredit. Pegadaian Unit Syariah Sigli sebagai data penelitian ini menerapkan adanya pembayaran DP (bayar dimuka) terhadap pembiayaan produk mulia ini sebelum melakukan angsuran pertama sebesar $15 \%$, biaya administrasi 50.000 , serta biaya mu'nah (biaya pemelihaan) sebesar 1\% dari harga jual beli produk Mulia tersebut, sebelumnya akad yang digunakan dalam Produk Mulia ini adalah akad murabahah sebagai akad pokok yang digunakan tetapi seiring perkembangan pada tanggal Kamis, 19 Oktober 2019 di update menggunakan akad ar-rahn, dan yang diketahui sekarang dijelaskan menurut teori mengenai ar-rahn akad ini biasanya digunakan sebagai akad pelengkap atau akad penunjang dari akad pokok agar bisa melakukan pembelian barang yang ditangguhkan dengan pembayaran yang tidak tunai atau kredit. Tetapi di lapangan akad ar-rahn digunakan menjadi akad pokok dengan melakukan pemesanan produk Mulia kepada pemasok sesuai dengan permintaan nasabah, Kemudian menjual produk Mulia kepada 
nasabah secara angsuran dengan harga pokok ditambah keuntungan. Peralihan akad ini dimaksudkan untuk mendapatkan lebih banyak keuntungan karena dalam akad murabahah jelas biaya-biaya yang akan dikeluarkan, sedangkan ar-rahn mengambil keuntungannya dari adanya biaya pemeliharaan, penitipan, penjagaan serta biaya penaksiran.(Very Satria,2019)

Alasan meneliti agar benar-benar paham akad ar-rahn yang digunakan dalam proses pembelian mulia secara angsuran dan memberikan pemahaman akan biaya yang ditanggung nasabah dalam akad ar-rahn. Seperti diketahui sebelumnya akad yang digunakan dalam Produk Mulia ini adalah akad murabahah sebagai akad pokok yang digunakan tetapi seiring perkembangan baru tanggal Kamis, 19 Oktober 2019 diupdate menggunakan akad ar-rahn pada PT. PT. Pegadaian Unit Syariah Sigli.

\section{KAJIAN LITERATUR Akad Ar-Rahn}

Akad ar-Rahn, terdiri dari dua kata yaitu akad dan ar-rahn, kata akad itu sendiri memiliki arti secara harfiah akad ar-rahn terdiri dari dua kata yaitu "akad" dan "ar-rahn". Kata akad dari segi bahasa berarti ikatan (ar-rabthu), mengikat, menyambung, atau menghubungkan (Syamsul Anwar, 2007) Menurut bahasa akad berasal dari padanan kata Al-'ahdu (Hendi Suhendi, 2014) yang bermakna janji, sebagaimana dijelaskan dalam AlQur'an, Surah Ali Imran ayat 76.

$$
\text { بلى من أوفى بعهده واتقى فإن الله يحب المتقين (آل عمران : V9) }
$$

(Bukan demikian), sebenarnya siapa yang menepati janji (yang dibuat) nya dan bertakwa, maka sesungguhnya Allah menyukai orang-orang yang bertakwa. (Ali-Imran: 76).

Menurut Zuhaly akad secara konseptual atau dalam isitlah syari'ah yang dikutip di buku Ismail Nawawi disebutkan, bahwa akad adalah hubungan atau keterikatan antara ijab dan qabul yang dibenarkan oleh syari'ah dan memiliki implikasi hukum tertentu. Dalam pengertian lain akad merupakan keterkaitan antara keinginan kedua belah pihak yang dibenarkan oleh syariah dan menimbulkan ilmpikasi hukum tertentu. (Ismail Nawawi, 2012). Adapun ar-rahn secara etimologi, berarti tetap, kekal, dan jaminan atau juga disebut dengan "al-tsubut dan al-habs berarti penetapan dan penahanan"( Hendi Suhendi, 2014).

Makna gadai (ar-rahn) dalam bahasa hukum positif disebut sebagai barang jaminan, agunan, dan rungguhan. Akad ar-rahn dalam istilah terminologi positif disebut dengan barang jaminan, agunan dan runggahan. Dalam Islam ar-rahn merupakan sarana saling tolong-menolong bagi umat Islam, tanpa adanya imbalan jasa (Haroen Nasrun, 2007). Sedangkan menurut istilah syara', yang dimaksud dengan ar-rahn adalah menjadikan suatu barang yang mempunyai nilai harta dalam pandangan syara' sebagai jaminan utang, yang memungkinkan untuk mengambil seluruh atau sebagian utang dari barang tersebut.( Abdul Ghofur Anshori, 2005). Ar-rahn adalah menahan salah satu harta milik si peminjam sebagai jaminan atas pinjaman yang diterimanya. Barang yang ditahan tersebut memiliki nilai ekonomis. Dengan demikian, pihak yang menahan memperoleh jaminan untuk dapat mengambil kembali seluruh atau sebagian piutangnya. Secara sederhana dapat dijelaskan bahwa ar-rahn adalah semacam jaminan utang atau gadai. (Sabbiq Sayyid, 2001). Para ulama fiqh mengemukakan bahwa akad ar-rahn dibolehkan 
dalam Islam berdasarkan al-Qur'an dan sunnah Rasul. Dalam surat al-Baqarah ayat 283 Allah berfirman:

$$
\begin{aligned}
& \text { وإن كنتم على سفر ولم تحدوا كاتبا فرهان مقبوضة فإن أمن بعضكم بعضا فليؤد الذي اؤتمن أمانته وليتق الله ربه }
\end{aligned}
$$

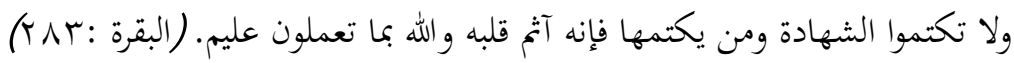

Jika kamu dalam perjalanan (dan bermu'amalah tidak secara tunai) sedang kamu tidak memperoleh seorang penulis, maka hendaklah ada barang tanggungan yang dipegang (oleh yang berpiutang). Akan tetapi jika sebagian kamu mempercayai sebagian yang lain, maka hendaklah yang dipercayai itu menunaikan amanatnya (hutangnya) dan hendaklah dia bertaqwa kepada Allah Rabbnya dan janganlah kamu (para saksi) menyembunyikan persaksian. Dan siapa yang menyembunyikannya, maka sesungguhnya dia adalah orang yang berdosa hatinya dan Allah Mengetahui apa yang kamu kerjakan. (Al-Baqarah: 283).( Departemen Agama RI, 2010)

Para ulama fiqh sepakat menyatakan bahwa ar-rahn boleh dilakukan dalam perjalanan dan dalam keadaan hadir di tempat, asal barang jaminan itu bisa langsung dipegang/dikuasai (al-qabdh) secara hukum oleh pemberi piutang. Maksudnya, tidak semua barang jaminan dapat dipegang atau dikuasai oleh pemberi piutang secara langsung, maka paling tidak ada semacam pegangan yang dapat menjamin bahwa barang dalam status al-marhun (menjadi agunan utang). Misalnya, apabila barang jaminan itu berbentuk sebidang tanah, maka yang dikuasai (al-qabdh) adalah surat jaminan tanah itu.( Haroen Nasrun,2007) Di samping itu, berdasarkan fatwa Dewan Syari'ah Nasional No. 25/DSN- MUI/III/2002, tanggal 26 Juni 2002 dinyatakan bahwa, pinjaman dengan menggadaikan barang sebagai jaminan hutang dalam bentuk ar-rahn dibolehkan. Jumhur ulama berpendapat bahwa ar-rahn disyariatkan pada waktu tidak bepergian maupun pada waktu bepergian. (Muhammad Sholekul Hadi, 2003)

\section{Rukun dan Syarat Ar-Rahn}

Berkenaan dengan rukun ar-rahn mayoritas ulama bersepakat bahwa rukun ar-rahn terdiri dari (1) Orang yang menggadaikan (rahin), (2) Orang yang meminta gadai (murtahin), (3) Barang yang digadaikan (marhun/rahn), (4) Utang (marhun bih), dan (5) Ucapan shighat (ijab dan qabul). Namun, ulama juga berbeda pendapat terhadap syarat akad ar-rahn yaitu sebagai berikut: (Ismail Nawawi, 2012)

Pihak-pihak yang melakukan perjanjian rahn, yakni rahin dan murtahin, harus mempunyai kemampuan, yaitu berakal sehat. Kemampuan juga berarti kelayakan seseorang untuk melakukan transaksi kepemilikan. Setiap orang yang sah untuk melakukan jual beli maka ia juga sah melakukan ar-rahn, karena gadai seperti ini yang melakukan pengelolaan harta. (Ismail Nawawi, 2012)

Shighat tidak boleh terikat dengan syarat tertentu dan juga dengan waktu di masa mendatang. Ar-rahn mempunyai sisi pelepasan barang dan pemberian utang seperti halnya akad jual beli, sehinga tidak boleh diikat dengan syarat tertentu atau dengan suatu waktu tertentu atau dengan waktu di masa depan.

Harus merupakan hak yang wajib diberikan dan diserahkan kepada pemiliknya dan memungkinkan pemanfaatannya. Bila sesuatu yang menjadi utang itu tidak bias dimanfaatkan maka tidak sah. Harus dikuantifikasikan atau dihitung jumlahnya. Bila 
tidak dapat diukur atau tidak dapat dikuantifikasikan, ar-rahn tidak sah. (Ismail Nawawi, 2012)

Menurut ulama Syafi-iyah, gadai bisa sah dengan dipenuhinya tiga syarat. Pertama, harus berupa barang, karena utang tidak bisa digadaikan. Kedua, penetapan kepemilikan penggadai atas barang yang digadaikan tidak terhalang. Ketiga, barang yang digadaikan bisa dijual manakala sudah tiba masa pelunasan utang gadai. Jadi, para ulama sepakat bahwa syarat pada gadai adalah syarat yang berlaku pada barang yang bisa diperjual belikan.

Syarat-syarat Barang ar-rahn di antaranya: harus bisa diperjualbelikan, harus berupa harta yang bernilai, Marhun harus bisa dimanfaatkan secara syari'ah, tidak berupa barang haram, harus diketahui keadaan fisiknya dan harus dimiliki oleh ar-rahn, setidaknya harus atas izin pemiliknya.

\section{Implementasi dan Mekanisme Ar-Rahn}

Penggunaan akad di dalam transaksi ar-rahn yang sering terjadi dan diakui secara syari'ah dapat dibagi menjadi dua yaitu : (Syelfi Bahtiana Putri, 2019)

- Akad Tabarru' adalah akad yang digunakan dengan tujuan untuk saling tolong menolong tanpa mengharapkan balasan kecuali Allah SWT. Dengan demikian, masing-masing pihak terlihat tidak dapat mengambil keuntungan (profit) dari jenis transaksi ini.

- Akad Tijarah adalah akad yang digunakan dalam transaksi dengan tujuan mencari keuntungan, besarnya keuntungan yang diperoleh ditentukan oleh kesepakatan masing-masingpihak yang bersangkutan. Dengan demikian, masing-masing pihak yang terlibat dapat mengambil keuntungan (profit) dari jenis transaksi ini.

Sedangkan implementasi akad ar-rahn dalam Pegadaian ada dua hal yaitu; (Syelfi Bahtiana Putri, 2019)

- Sebagai produk pelengkap, artinya ar-rahn digunakan sebagai akad tambahan (jaminan/collateral) terhadap produk lain seperti dalam pembiayaan bai'al murabahah. Pegadaian dapat menahan barang nasabah sebagi konsekuensi ekad tersebut.

- Sebagai Produk tersendiri, artinya akad ar-rahn telah digunakan sebagai alternatif dari pegadaian konvensional. Bedanya dengan pegadaian biasa, dalam ar-rahn nasabah tidak digunakan bunga, yang dipungut dari nasabah adalah biaya penitipan, pemeliharaan, penjagaa, serta penaksiran.

Dalam mekanisme perjanjian akad ar-rahn, akad perjanjian yang dapat dilakukan antara lain: (Syelfi Bahtiana Putri, 2019):

- Akad al-qardhul hasan. Akad ini dilakukan pada kasus nasabah yang menggadaikan barangnya untuk keperluan kinsumtif. Dengan demikian, nasabah (rahin) akan memberikan biaya upah atau fee kepada pegadaian (murtahin) yang telah menjaga atau merawat barang gadaian (marhun).

- Akad al-mudharabah. Akad ini dilakukan untuk nasabah yang menggadaikan jaminannya untuk menambah modal usaha. Dengan demikian, rahin akan 
memerikan bagi hasil (berdasarkan keuntungan) kepada murtahin sesuai dengan kesepakatan, sampai modal yang dipinjam terlunasi.

- Akad ba'i al muqayyadah. Akad ini dilakukan untuk nasabah yang menggadaikan barang jaminannya untuk menambah modal usaha berupa pembelian barang modal. Dengan demikian murtahin akan membelikan barang yang dimaksud rahin.

\section{Metode Penelitian}

Penelitian yang dilakukan adalah peneltian survei guna untuk membantu tugas akhir peneliti yang dijadikan sebagai bahan untuk mnenelusuri penerapan akad ar-rahn yang digunakan sebagai akad pokok. Metode penelitian yang digunakan adalah metode deskriptif analisis dengan jenis penelitian kualitatif. Penelitian kualitatif adalah suatu pendekatan atau penelusuran untuk mengekspolarasi dan memahami gejala sentral dengan mengajukan pertanyaan umum dan meluas (J.R. Raco, 2010). Adapun corak penelitian ini merupakan penelitian lapangan dengan menggunakan analisis deskriptif, analisis bertujuan untuk menjelaskan semua yang berkaitan dengan judul ini, mendeskripsikan apa adanya, mencatat, menganalisis, dan menginterprestasikan secara lengkap kondisi-kondisi yang terjadi. Penelitian ini juga dipadukan dengan penelitian kepustakaan, guna membantu melengkapi data-data yang dibutuhkan mengenai penjelasan akad ar-rahn. Data wawancara yang didapatkan pra penelitian dan saat penelitian selanjutnya diolah untuk mampu memcahkan permasalahan yang didapatkan pada saat penelitian.

\section{HaSil dan PEMBahasan}

\section{Ketentuan dan Mekanisme Transaksi ar-Rahn di Pegadaian Syariah Unit Sigli}

Pembiayaan Mulia dengan akad ar-rahn sudah dijelaskan di atas salah satu produk yang dikeluarkan oleh Pegadaian Unit Syariah Sigli ini memudahkan masyarakat dalam memenuhi kebutuhnnya terutama dari segi Investasi untuk kebutuhan masa depan yang sangat mudah serta fleksibel. Produk Mulia adalah layanan penjualan emas batangan kepada masyarakat secara tunai atau angsuran dengan proses mudah dan jangka waktu yang fleksibel. Mulia dapat menjadi alternatif pilihan investasi yang aman untuk mewujudkan kebutuhan masa depan, sepertimenunaikan ibadah haji, mempersiapkan biaya pendidikan anak, memiliki rumah idaman serta kendaraan pribadi. Persyaratan serta mekanisme dalam pengajuan pembiayaan Mulia dapat langsung datang ke Pegadaian Unit Syariah Sigli manapun dengan membawa persyaratan yang ditentukan pada Pegadaian setepat.

Ketentuan dari Produk Mulia yang harus dipahami oleh masyarakat diantaranya sebagai berikut;

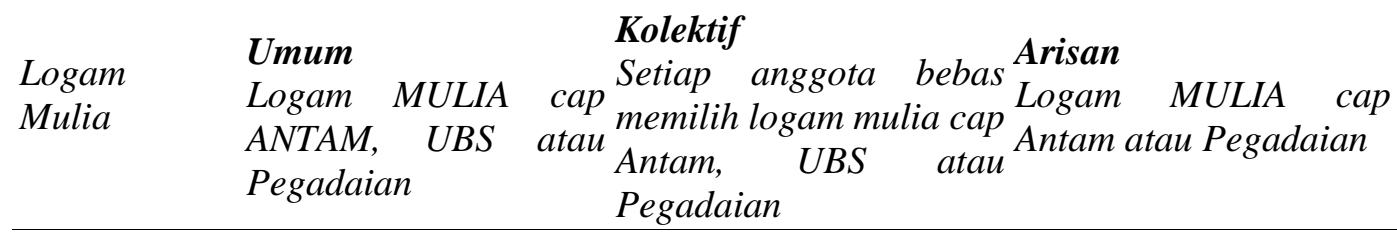




\begin{tabular}{|c|c|c|c|}
\hline \multicolumn{2}{|c|}{ Jangka Waktu 3/6/12/18/24/36 bulan } & \multicolumn{2}{|c|}{$\begin{array}{l}\text { Setiap anggota bebas Sesuai dengan jumlah } \\
\text { memilih } 3 / 6 / 12 / 18 / 24 / 36 \text { anggota minimal } 6 \text {, } \\
\text { bulan, min. } 6 \text { orang maks. } 36 \text { orang orang }\end{array}$} \\
\hline $\begin{array}{l}\text { Uang Muka } \\
\text { Minimal }\end{array}$ & $15 \%$ & $10 \%$ & $10 \%$ dan $15 \%$ \\
\hline $\begin{array}{l}\text { Pengambilan } \\
\text { LM }\end{array}$ & Setelah lunas & $\begin{array}{l}\text { Setelah lunas masing- } \\
\text { masing anggota }\end{array}$ & $\begin{array}{l}\text { Satu keping per bulan, } \\
\text { untuk UM } 10 \% \text { dimulai } \\
\text { setelah angsuran ke- } 2 \text {, } \\
\text { untuk UM } 15 \% \text { dimulai } \\
\text { setelah angsuran ke-1 }\end{array}$ \\
\hline $\begin{array}{l}\text { Akad } \\
\text { Pembiayaan }\end{array}$ & Satu akad & $\begin{array}{l}\text { Satu akad masing- } \\
\text { masing anggota }\end{array}$ & Satu akad \\
\hline $\begin{array}{l}\text { Biaya } \\
\text { Administrasi }\end{array}$ & Rp. 50.000,- & Rp. 50.000,- per anggota & Rp. 50.000, \\
\hline
\end{tabular}

Pada produk pembiayaan Mulia dalam jual beli secara angsuran di Pegadaian Syariah Unit Sigli menggunakan akad ar-rahn mulai diterapkan pada kamis, 19 Oktober 2020 dalam akad ar-rahn pada produk pembiayaan Mulia ini bahwa Pegadaian Syariah Unit Sigli yang merupakan pihak pertama memberikan fasilitas pembiayaan ar-rahn sebagai akad pokok kepada pihak nasabah sebagai pihak kedua dengan syarat-syarat dan ketentuan yang berlaku. Akad ar-rahn pada pembiayaan Mulia pihak nasabah (rahin) sepakat untuk menyerahkan barang miliknya sebagai jaminan hutang. Akad ar-rahn sebagaimana di definisikan oleh para ulama adalah menjadikan barang berharga menurut tinjauan syariat sebagai jaminan hutang, sekiranya pembayaran hutang atau sebagian bisa diambil dari benda yang digadaikan tersebut. Jaminan pelunasan hutang. Aplikasi pembiayaan Mulia minimal melibatkan tiga pihak yaitu Pegadaian Syariah selaku pembeli atau pembeli yang membiayai barang nasabah. (Nurmasyitah, 2020)

\section{Pengelolaan Biaya Administrasi dan Biaya Pemeliharaan Barang Jaminan}

Perusahaan menjamin keutuhan dan keamanan marhun yang dijadikan jaminan di Unit Layanan Gadai Syariah. Disamping itu proses transaksi pinjam-meminjam pada sistem gadai syariah membutuhkan perlengkapan kerja seperti alat tulis kantor, perlengkapan dan biaya tenaga kerja serta rahin dijaminankan pada perusahaan asuransi. Oleh karena itu rahin dibebankan biaya administrasi yang besarnya sesuai dengan nilai taksiran dan jumlah pinjaman nasabah yang oleh PT. Pegadaian telah ditentukan dengan kebijakan penentuan golongan marhun. Berikut adalah golongan marhun bih berdasarkan tingkat pinjaman/plafon dan besarnya biaya adminsistrasinya didasarkan pada: (Very Satria, 2020)

- Biaya Riil yang dikeluarkan, seperti perlengkapan dan biaya tenaga kerja serta rahin dijaminkan pada perusahaanasuransi.

- Besarnya biaya administrasi ditetapkan dalam Surat Edaran (SE) itu sendiri.

- Dipungut dimuka pada saat pinjaman dicairkan.

Tarif biaya administrasi murah dan tidak memberatkan atas transaksi marhun bih ditetapkan sebesar Rp. 50.000,-untuk setiapkelipatanmarhun bih Rp. 5.000,-untuk semua golongan marhun bih. Terhadap hasil hitungan biaya administrasi ini dilakukan pembulatan ke Rp. 100 terdekat Rp. 1 s/d Rp. 50,- dianggap sama dengan 0 (nol) diatas Rp. 50,- s/d Rp. 100 dibulatkan ke Rp. 100. Biaya administrasi dikenakan hanya sekali 
pada saat akad. (Very Satria, 2020) Dalam praktiknya Pegadaian Syariah membelikan barang yang diperlukan nasabah atas nama Pegadaian. Pada saat yang bersamaan Pegadaian menjual barang tersebut kepada nasabah dengan harga pokok ditambah dengan sejumlah biaya-biaya untuk dibayar oleh nasabah pada jangaka waktu tertentu, kemudian barang yang dibeli yaitu berupa emas dijadikan jaminan (marhun) untuk pelaksanaan sisa hutang nasabah kepada pihak Pegadaian Unit Syariah Sigli.

Apabila nasabah tidak melakukan kewajiban membayar angsuran pada tanggal yang telah ditetapkan, jika keterlambatan pembayaran angsuran sampai dengan 7 hari maka di kenakan denda sebesar $2 \%$ dan denda besaran maksimalnya $4 \%$ dibagi 30 hari dala sebulan. Jika nasabah belum juga membayar angsuran selama (dua) 2 bulan maka emas yang dijadikan jaminan hutang tetap berada dibawah kekuasaan Pegadaian Unit Syariah Sigli untuk disimpan dan dijual jika sewaktu-waktu ada nasabah lain yang ingin memesan dan atau dilelang. Dana hasil dari denda nasabah sepenuhnya akan digunakan untuk dana sosial. (Very Satria, 2020)

\section{Tinjauan Hukum Islam Tentang Akad Ar-Rahn di Pegadaian Syariah Unit Sigli}

Pegadaian Unit Syariah Sigli merupakan lembaga keuangan non-bank yang bertugas menyalurkan pembiayaan dalam bentuk pemberian pinjaman kepada masyarakat berlandaskan hukum gadai syariah. Namun kini banyak produk pembiayaan yang ditawarkan Pegadaian Unit Syariah Sigli. Salah satunya yaitu pembiayaan mulia yang merupakan fasilitas jual beli emas secara angsuran proses yang mudah dan jangka waktu yang fleksibel. Dalam jual beli emas secara angsuran ini mensyaratkan penyerahan barang jaminan (mahrun) oleh nasabah ke Pegadaian Syariah.(Nurmasyitah, 2020). Sehingga dalam transaksi Pembiayaan mulia Pegadaian Unit Syariah Sigli menerapkan akad perjanjian yaitu akad ar- rahn. Akad ar- rahn di sini digunakan sebagai akad pokok dalam proses Mulia yaitu menahan harta milik nasabah sebagai jaminan atas hutang yang diterimanya, pihak yang menahan memperoleh jaminan untuk mengambil kembali seluruh atau sebagian piutangnya. Dengan akad ini Pegadaian Unit Syariah Sigli menahan barang yang menjadi objek transaksi yaitu emas logam mulia. Akad ar- rahnini merupakan akad tabarru' yaitu akad yang dipergunakan utuk tujuan saling menolong tanpa mengharap imbalan kecuali dari Allah SWT.

Hasil Wawancara dengan Tokoh agama di Rambayan, Kecamatan Peukan Baro, Akad yang digunakan dalam pembiayaan mulia yaitu akad ar-rahn telah sesuai dengan syarat dan rukun menurut hukum Islam baik yang menyangkut para pihak, objek perjanjian, maupun sighat (Ijab dan Qabul) dengan syarat kedua belah pihak memahami dan mengerti mengenai akad ar-rahn yang digunakan dalam produk Mulia ini serta telah sepakat kedua belah pihak dengan iuran dan biaya-biaya yang dikeluarkan oleh pihak Pegadaian Unit Syariah Sigli. ( Ustazah Cut Fatimah, 2020)

Persyaratan dan prosedur pembiayaan mulia yang telah ditentukan oleh Pegadaian Unit Syariah Sigli dengan kaidah-kaidah hukum Islam yaitu persyaratan sederhana, prosedurnya mudah, akad secara tertulis, pembiayaan atau hutang dengan jaminan barang yang sudah dibeli, tidak dipungut bunga, keuntungan margin dan isi perjanjian disepakati oleh kedua belah pihak serta pembiayaan tidak mengandung gharar. Hal ini didasarkan dengan adanya kejelasan akad ar-rahn yang dilakukan sesuai kesepakatan kedua belah pihak. Akad ar-rahn merupakan akad pokoknya. Pembiayaan mulia diperbolehkan karena tidak mengandung riba maupun gharar serta barang jaminan sudah menjadi milik nasabah ketika terjadinya akadar-rahn.. (Ustazah Cut Fatimah, 2020) 
Berdasarkan penjelasan yang telah dipaparkan di atas, akad dalam pembiayaan mulia yaitu dan akad ar-rahn merupakan prosedur yang telah ditentukansesuai batas kewajaran, dimana merupakan wujud kehati-hati pihak Pegadaian Unit Syariah Sigli dalam menghadapi resiko tidak terbayar oleh nasabah, sebagaimana dalam penetapan uang muka, penetapan keuntungan (margin), penetapan jaminan (marhun), penetapan denda dan ketentuan lainnya, maka hal itu diperbolehkan karena telah disepakati oleh kedua belah pihak pada Ijab dan Qabul. ( Ustazah Cut Fatimah, 2020)

Selain itu, ada juga Tokoh Agama Kecamatan Kota Sigli sebagai informan berpendapat bahwa akad ar-rahn yang digunakan dalam pada produk Mulia ini tidak sesuai dengan hukum Islam karena adanya biaya-biaya yang dibebankan di dalamnya kepada para nasabah, mulai dari biaya administrasi, biaya pemeliharaan serta biaya denda jika tertungga pembayaran angsuran, yang di mana biaya tersebut dapat memberatkan pihak nasabah dan berpotensi ke dalam gharar yang diharamkan dalam hukum Islam. (Teungku Tarmizi Sabi, 2020)

\section{KESIMPULAN}

Berdasarkan penelitian yang dilakukan dengan tujuan penyelesaian tugas akhir strata satu ini bahwa akad dalam pembiayaan produk Mulia di Pegadaian Unit Syariah Sigli dipandang sah oleh hukum Islam, kegiatan muamalah tidak bertentangan dengan syara'. Pembiayaan Mulia dengan akad ar-rahn diperbolehkan karena didasarkan dengan adanya kejelasan antara kedua belah pihak, yaitu pihak Pegadaian Unit Syariah Sigli dan nasabah pada saat melakukan pembelian produk Mulia yang dilakukan sesuai kesepakatan serta saling ridha kedua belah pihak pada saat Ijab dan Qabul. Persyaratan dan prosedur pembiayaan Mulia yang telah ditentukan oleh Pegadaian Unit Syariah Sigli dengan kaidah-kaidah hukum Islam yaitu persyaratan sederhana, prosedurnya mudah, akad secara tertulis, pembiayaan atau hutang dengan jaminan barang yang sudah dibeli, tidak dipungut bunga, keuntungan margin dan isi perjanjian disepakati oleh kedua belah pihak serta pembiayaan tidak mengandung gharar. Akan tetapi dalam praktiknya nasabah tetap dirugikan, karena harus membayar dua kali lipat yaitu hutang ar-rahn dan biaya penyimpanan atas barang jaminan, serta biaya administarsi yang pada gilirannya bisa berpotensi menimbulkan gharar.

\section{REFERENSI}

Antonio, Syafi'i. 2001. Bank Syariah dari Teori ke Praktik. ed I. Jakarta: Gema Insani Press.

Anwar, Syamsul. 2007. Hukum Perjanjian Syariah: Studi Tentang Teori Akad dalam Fikih Muamalat. Jakarta: PT. Raja Grafindo Persada

Ghofur, Abdul Anshori. 2005. Gadai Syariah di Indonesia: Konsep, Implementasi dan Institusionalisai. Yogyakarta: Gadjah Mada University Press.

Pendidikan, Departemen Agama RI. 2010. Al-Qur'an dan Terjemahnya. Bandung: Penerbit Diponegoro.

R, J. Raco. 2010. Metode Penelitian Kualititatif, Jenis, Karakter dan Keunggulan .Jakarta: PT. Gramedia Widiasarana, Indonesia 
Nasrun, Haroen. 2007. Fiqh Muamalah. Jakarta: Gaya Media Pratama.

Nawawi,Ismail. 2012. Fikih Mu'amalah Klasik dan Kontemporer. Bogor: Ghalia Indonesia

Sabbiq, Sayyid (Jilid 4). 2016. Fiqih Sunnah. Sukoharjo: Penerbit Insan Kamil

Sholekul, Muhammad Hadi. 2003. Pegadaian Syariah, Cet. I. Jakarta: Selemba Diniyah

Suhendi, Hendi. 2014. Fqih Muamalah. Jakarta: PT Raja Grafindo Persada

Syafe'i, Rachmat. 2001. Fiqih Muamalah. Bandung: Pustaka Setia

Bahtiana, Syelfi Putri. 2019. Analisis Implementasi Akad Rahn Pada Produk Mulia di Pegadaian Syariah Way Halim Bandar Lampung. UIN Raden Intan, mpung.

Maghfirah, Nurlaili. 2018. Mekanisme Akad Murabahah Dalam Penjualan Produk Mulia Arisan Pada Pegadaian Syariah Banda Aceh. UIN Darussalam, Banda Aceh

Direktur (Wanwancara, 2020)

Staf Custumer Service ( Wawancara, 2020)

Pimpinan Dayah (Wawancara, 2020)

Teungku Imam Meunasah ( Wawancara, 2020) 